CLINICAL STUDY

\title{
Correlation between leptin level and hypertension in normal and obese pre- and postmenopausal women
}

\author{
Kawaljit Kaur Khokhar ${ }^{1}$, Sharda Sidhu ${ }^{1}$ and Gurcharan Kaur ${ }^{2}$ \\ Departments of ${ }^{1}$ Human Genetics and ${ }^{2}$ Biotechnology, Guru Nanak Dev University, Amritsar 143005, Punjab, India \\ (Correspondence should be addressed to G Kaur; Email: kgurcharan.neuro@yahoo.com)
}

\begin{abstract}
Objective: The present study was aimed at evaluating the correlation between leptin and hypertension in normal and obese hypertensive pre- (Pre-M) and postmenopausal (Post-M) women of Jalandhar city (Punjab, India).

Design: For the present study, 78 Pre-M and Post-M women were recruited in four categories as follows: i) normal normotensive, ii) obese normotensive, iii) normal hypertensive, and iv) obese hypertensive. Body mass index was considered as the index of obesity. Guidelines given by JNC-VII were followed for the assessment of hypertension. Leptin was assayed by sandwich ELISA, and estradiol $\left(\mathrm{E}_{2}\right)$ was assayed by competitive ELISA.

Results: Leptin level was found to be significantly higher in normal Pre-M women $(P<0.02)$ than that of normal Post-M women. Obese subjects had significantly higher leptin level $(P<0.001)$ than the normal women. In the case of hypertensive subjects, leptin level was significantly higher than that of normotensive counterparts. $E_{2}$ level was found significantly lower in Post-M women $(P<0.001)$ than that of Pre-M women as well as in hypertensive women than that of normotensive subjects. A positive correlation was observed between blood pressure (BP) and leptin, but significant association was observed in hypertensive normal and obese Pre-M and Post-M women only.

Conclusion: It is concluded from the present findings that leptin contributes to the regulation of BP in hypertensive normal as well as in the obese Pre-M and Post-M women. So, leptin may be a regulator of $\mathrm{BP}$ in hypertensive women independent of the degree of obesity and the menopausal status.
\end{abstract}

European Journal of Endocrinology 163 873-878

\section{Introduction}

Leptin is a key neuroendocrine hormone, which plays an important role in regulating food intake, metabolism, and fat accumulation, and it may also affect blood pressure (BP) and contribute to hypertension through sympathetic activation in the vasculature or at the renal level (1-3). Leptin's role in causing hypertension has been almost unapproached until leptin was discovered in 1994. Cross-sectional investigation in human subjects shows increasing leptin concentrations with rise in BP in both the normotensive (4) and hypertensive range $(5,6)$. The high risk of developing cardiovascular diseases in obese subjects has also drawn attention to study the neurohormonal effects of leptin on cardiac functioning and remodeling. A relationship between the circulating leptin level with hypertension and associated cardiovascular morbidity has been reported recently $(3,7,8)$. Kramer et al. (9) also observed increased leptin levels among hypertensive elderly subjects and reported that higher leptin level increases $70 \%$ chances of risks for subsequent hypertension.

Leptin level has been shown to be higher in premenopausal (Pre-M) women than that of postmenopausal (Post-M) women suggesting a stimulatory effect of estrogen and/or progesterone and an inhibitory action of androgens on leptin levels (10). Obese individuals for some unknown reasons become resistant to the appetite and weight-reducing effects of leptin. So, the level of leptin increases in obese subjects (11). The association between hypertension and obesity suggests that adipose tissue may play an important role in the regulation of BP (12).

The present study was designed to compare the serum leptin levels in normal and obese Pre-M and Post$\mathrm{M}$ women of Jalandhar city (Punjab, India), and further the possible correlation between leptin level and BP was evaluated to find out whether serum leptin is a predictor of BP in the hypertensive women.

\section{Subjects and methods}

For the present cross-sectional study, data were collected from 78 educated working females in the age group of 30-60 years from Jalandhar city (Punjab, India). The study was approved by the Guru Nanak Dev University ethical review committee. The written 
consent was obtained from the subjects after explaining the objectives as well as the methodology of the study. Each subject was personally interviewed to evaluate whether she corresponded to the study's criteria for menopausal status, hormone therapy, and other medication. Subjects who reported that they did not have their menses for at least 1 year were considered as Post-M (13) and were included in the study. Women who had regular menstrual periods at the time of examination were considered as Pre-M. Subjects undergoing hormone therapy were excluded from the study. Anthropometric measurements like height, weight, and skin folds (biceps, triceps, suprailiac, and subscapular) were taken with standard methods (14). Body mass index (BMI) was calculated as per criteria given by World Health Organization (WHO) and International Obesity Task Force (IOTF) (15). Subjects with BMI $\geq 25 \mathrm{~kg} / \mathrm{m}^{2}$ were considered as obese, and subjects with BMI 18.5-22.9 kg/m ${ }^{2}$ were considered as normal (15). BP was measured using auscultatory technique with mercury sphygmomanometer as in normal clinical practice. The subjects were seated with arm supported at heart level, and BP was calculated twice with an interval of $5 \mathrm{~min}$ (16). The average systolic BP (SBP) and diastolic BP (DBP) measurements were calculated was assessed using standard criteria formulated by JNC-VII (17). Subjects with SBP $\geq 140 \mathrm{mmHg}$ and DBP $\geq 90 \mathrm{mmHg}$ were considered as hypertensive. Fat mass (FM) was calculated from percent body fat according to the method devised by Durnin \& Womerslay (1974) (18).

\section{Study design}

Subjects were divided into two groups; Pre-M (39) and Post-M (39). They were further categorized as normal normotensive (9), obese normotensive (10), normal hypertensive (10), and obese hypertensive (10). Fasting blood samples were collected; serum was separated and stored in aliquots in the freezer. Leptin was estimated by sandwich ELISA, using Leptin ELISA Kit manufactured by Bio-Line, S.A., Brussels (Belgium). The intra-assay and inter-assay coefficients of variation were 3.6 and $5.2 \%$ respectively. Estradiol $\left(\mathrm{E}_{2}\right)$ was estimated by competitive ELISA using $\mathrm{E}_{2}$ Kit manufactured by Adaltis Italia (Cassalecchio di Reno, Italy). The intra-assay coefficient of variation was $4.8-7.2 \%$, and inter-assay coefficient of variation was $5.4-9.6 \%$. We assayed levels of leptin and $\mathrm{E}_{2}$ in normal and obese Pre-M and Post-M hypertensive women and compared these values with their normotensive counterparts. Additionally, the influence of BMI, FM, and BP on leptin levels was evaluated.

\section{Leptin assay}

Leptin level was assayed by solid-phase sandwich enzyme immunoassay. The assay used MABs immobilized on for each subject. Hypertension status of study sample

www.eje-online.org

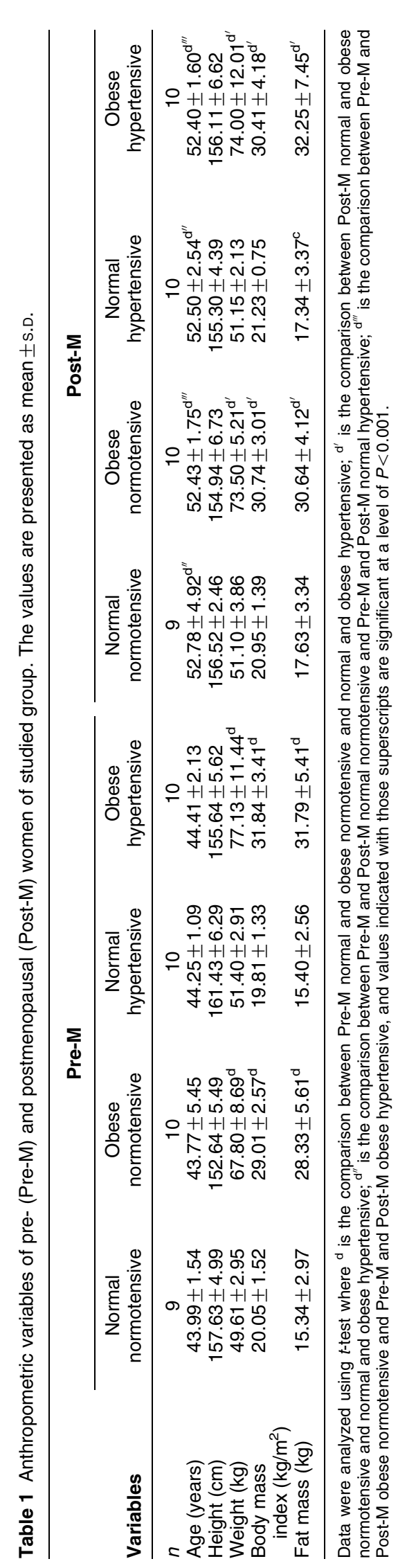


microtiter plates to which the standards and the samples reacted. After an incubation period, the bound enzymelabeled antibody was measured through a chromogen reaction. Absorbance was read at $450 \mathrm{~nm}$, and leptin concentration was determined.

\section{$E_{2} \operatorname{assay}$}

$\mathrm{E}_{2}$ was estimated by competitive type immunoassay where HRP-labeled $E_{2}$ competed with $E_{2}$ present in the patient sample for a fixed and limited number of antibody sites immobilized on the wall of the microstrip. After incubation, the absorbance of the solution was read at $450 \mathrm{~nm}$.

\section{Statistical analysis}

Data were maintained on a questionnaire proforma and then managed on an excel spreadsheet. Data analyses were performed using SPSS 16.0 (SPSS Inc., Chicago, IL, USA) for Windows. Results were presented as mean \pm s.D. The differences in anthropometric, physiological, and biochemical variables between Pre-M and Post-M women were calculated using $t$-test. We used ANOVA method to analyze the comparison between the groups. Pearson's correlation was computed to observe the correlation of leptin with the different variables. Forward stepwise multiple linear regression analysis was performed to analyze the independent effects of predictor variables.

\section{Results}

Table 1 shows anthropometric characteristics of Pre-M and Post-M women. Pre-M women were of lower age than Post-M women, whereas both the groups were matching for height, weight, BMI, and FM in all the categories. Table 2 presents the physiological and biochemical variables of the studied groups. The mean value of SBP was found significantly higher in normotensive normal $(P<0.02)$ and obese $(P<0.05)$ as well as hypertensive normal $(P<0.001)$ Post-M women than that of Pre-M counterparts. Similarly, the mean value of DBP was found significantly higher in the hypertensive normal $(P<0.001)$ and obese $(P<0.001)$ Post-M subjects than that of Pre-M counterparts. Leptin level was found significantly higher in the obese Pre-M and Post-M women $(P<0.001)$ than that of the normal subjects. Furthermore, both normal and obese hypertensive Pre-M women showed significantly higher leptin level than normotensive counterparts $(P<0.01$ and $P<0.001$ respectively). Similar trend in the leptin level was observed in the Post-M women. Normal and obese hypertensive Post-M women had higher leptin levels than normotensive counterparts $(P<0.01$ and $P<0.05$ respectively). On comparison between Pre-M and Post$\mathrm{M}$ women, the leptin level was found higher in the

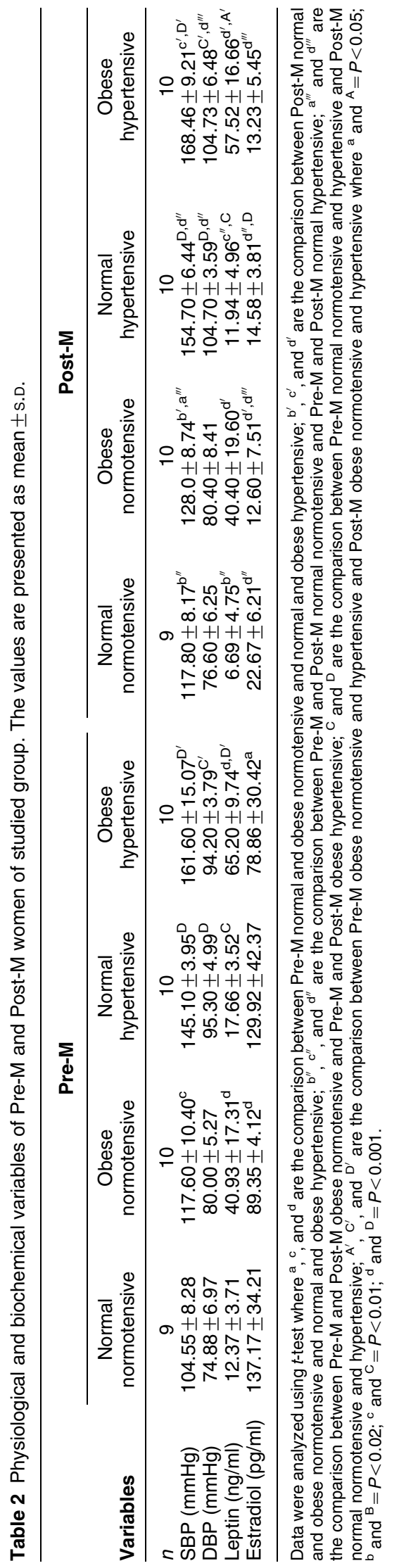

www.eje-online.org 
Table 3 Pearson's correlation of leptin with anthropometric, physiological, and biochemical variables in normotensive subjects.

\begin{tabular}{|c|c|c|c|c|c|c|c|c|}
\hline \multirow[b]{3}{*}{ Variables } & \multicolumn{4}{|c|}{ Pre-M } & \multicolumn{4}{|c|}{ Post-M } \\
\hline & \multicolumn{2}{|c|}{ Normal } & \multicolumn{2}{|c|}{ Obese } & \multicolumn{2}{|c|}{ Normal } & \multicolumn{2}{|c|}{ Obese } \\
\hline & $r$ & $P$ value & $r$ & $P$ value & $r$ & $P$ value & $r$ & $P$ value \\
\hline Age (years) & 0.024 & 0.950 & -0.330 & 0.352 & -0.081 & 0.823 & 0.158 & 0.698 \\
\hline Height $(\mathrm{cm})$ & -0.463 & 0.209 & 0.293 & 0.413 & 0.201 & 0.571 & -0.208 & 0.592 \\
\hline Weight (kg) & 0.679 & $0.044^{\star}$ & 0.755 & $0.011^{\star}$ & 0.905 & $0.000^{\ddagger}$ & 0.567 & 0.087 \\
\hline BMI $\left(\mathrm{kg} / \mathrm{m}^{2}\right)$ & 0.918 & $0.000^{\ddagger}$ & 0.870 & $0.000^{\ddagger}$ & 0.965 & $0.000^{\ddagger}$ & 0.882 & $0.000^{\ddagger}$ \\
\hline Fat mass $(\mathrm{kg})$ & 0.844 & $0.004^{\dagger}$ & 0.855 & $0.001^{\ddagger}$ & 0.970 & $0.001^{\ddagger}$ & 0.794 & $0.006^{\dagger}$ \\
\hline $\mathrm{SBP}(\mathrm{mmHg})$ & 0.460 & 0.213 & 0.522 & 0.139 & 0.575 & 0.105 & 0.320 & 0.367 \\
\hline $\mathrm{DBP}(\mathrm{mmHg})$ & 0.458 & 0.215 & 0.529 & 0.116 & 0.493 & 0.178 & 0.307 & 0.380 \\
\hline Estradiol $(\mathrm{pg} / \mathrm{ml})$ & 0.871 & $0.002^{\dagger}$ & 0.429 & 0.216 & 0.737 & $0.023^{\star}$ & 0.025 & 0.943 \\
\hline
\end{tabular}

BMI, body mass index; SBP, systolic blood pressure; DBP, diastolic blood pressure. ${ }^{\star} P \leq 0.05,{ }^{\dagger} P \leq 0.01,{ }^{\ddagger} P \leq 0.001$.

normotensive as well as hypertensive Pre-M subjects than that of Post-M counterparts. $\mathrm{E}_{2}$ level was significantly higher in the Pre-M women than that of the Post-M women $(P<0.001)$. In Pre-M group, $\mathrm{E}_{2}$ level was significantly higher in the normal subjects than that of the obese women in both normotensive $(P<0.001)$ and hypertensive categories $(P<0.05)$.

We performed ANOVA to compare non-obese (BMI $<23.0$ ) and obese (BMI $\geq 23.0$ ) normotensive and hypertensive Pre-M and Post-M women. The models were highly significant among both Pre-M and Post-M groups. The post hoc analysis revealed significant differences for serum leptin and SBP levels between normotensive and hypertensive Pre-M (leptin, $F=55.76$, $P<0.001$; SBP, $F=60.76, P<0.001)$ as well as Post-M women (leptin, $F=30.82, P<0.001$; SBP, $F=93.78$, $P<0.001)$. Pearson's correlation revealed significant correlation of leptin with BMI and FM in all categories and BP in hypertensive subjects only (Tables 3 and 4). We, additionally, performed a forward stepwise multiple regression analysis using leptin as a dependent variable to evaluate the independent influence of $\mathrm{BP}$ on serum leptin concentration in the Pre-M and Post-M hypertensive subjects. We entered age, weight, height, BMI, FM, $\mathrm{E}_{2}$, SBP, and DBP in stepwise multiple linear regression models. The analysis revealed that there was significant influence of SBP on leptin levels, even after controlling FM and BMI in hypertensive subjects $(\beta=0.206, t=4.99, P<0.001)$. No correlation was observed between $\mathrm{E}_{2}$ level and hypertension in both the Pre-M and Post-M subjects.

\section{Discussion}

Higher leptin level in hypertensive than that of normotensive women shown in the present data clearly suggests a direct correlation between leptin level and hypertension among the Pre-M and Post-M subjects. These data are supported by the previous reports, but these studies have been carried out either in the obese Pre-M and Post-M subject (3) or in the lean Pre-M and Post-M women (19). Similarly, Haque et al. (20) reported correlation between leptin and BP in adult females, but this study did not take into account the menopausal status of the women. Furthermore, the present data clearly indicate that leptin level in the normotensive as well as hypertensive Post-M women is significantly lower than that of the Pre-M subject. Since these Pre-M and Post-M subjects had matching values for BMI and FM, so the decline in leptin levels may be attributed to the menopausal status. Recent

Table 4 Pearson's correlation of leptin with anthropometric, physiological, and biochemical variables in hypertensive subjects.

\begin{tabular}{|c|c|c|c|c|c|c|c|c|}
\hline \multirow[b]{3}{*}{ Variables } & \multicolumn{4}{|c|}{ Pre-M } & \multicolumn{4}{|c|}{ Post-M } \\
\hline & \multicolumn{2}{|c|}{ Normal } & \multicolumn{2}{|c|}{ Obese } & \multicolumn{2}{|c|}{ Normal } & \multicolumn{2}{|c|}{ Obese } \\
\hline & $r$ & $P$ value & $r$ & $P$ value & $r$ & $P$ value & $r$ & $P$ value \\
\hline Age (years) & 0.754 & $0.012^{*}$ & 0.084 & 0.804 & -0.155 & 0.670 & -0.026 & 0.942 \\
\hline Height (cm) & -0.500 & 0.141 & 0.651 & $0.033^{\star}$ & -0.077 & 0.831 & -0.111 & 0.761 \\
\hline Weight (kg) & 0.144 & 0.690 & 0.841 & $0.000^{\dagger}$ & 0.656 & $0.039^{*}$ & 0.700 & $0.024^{*}$ \\
\hline $\mathrm{BMI}\left(\mathrm{kg} / \mathrm{m}^{2}\right)$ & 0.718 & $0.019^{*}$ & 0.723 & $0.011^{\dagger}$ & 0.956 & $0.000^{\ddagger}$ & 0.870 & $0.000^{\ddagger}$ \\
\hline Fat mass (kg) & 0.663 & $0.034^{\star}$ & 0.837 & $0.000^{\ddagger}$ & 0.760 & $0.010^{\dagger}$ & 0.896 & $0.000^{\ddagger}$ \\
\hline $\mathrm{SBP}(\mathrm{mmHg})$ & 0.708 & $0.020^{\dagger}$ & 0.944 & $0.000^{\ddagger}$ & 0.945 & $0.000^{\ddagger}$ & 0.763 & $0.010^{\dagger}$ \\
\hline DBP (mmHg) & 0.829 & $0.003^{\dagger}$ & 0.789 & $0.007^{\ddagger}$ & 0.869 & $0.000^{\ddagger}$ & 0.881 & $0.000^{\ddagger}$ \\
\hline Estradiol (pg/ml) & 0.487 & 0.602 & 0.242 & 0.747 & 0.876 & $0.000^{\ddagger}$ & 0.258 & 0.472 \\
\hline
\end{tabular}

BMI, body mass index; SBP, systolic blood pressure; DBP, diastolic blood pressure. ${ }^{\star} P \leq 0.05,{ }^{\dagger} P \leq 0.01,{ }^{\ddagger} P \leq 0.001$. 
studies $(6,21)$ reported that leptin levels are associated with increased risk for hypertension in subjects who were adjusted for age, BMI, insulin, and creatinine, etc. Chronic hyperleptinemia has been shown to enhance sympathetic nervous activity and reduces nitric oxidedependent vasodilation and natriuresis (22).

The previous studies have reported that leptin stimulates renin-angiotensin $(23,24)$ and sympathetic system (12), which may affect BP level in humans. Leptin also stimulates natriuresis. So, it is possible that a blunted effect of leptin may predispose to hypertension in humans $(25,26)$. Scientists have observed the relationship between serum leptin and heart beat in hypertensive subjects $(27,28)$. Role of leptin in causing cardiovascular diseases and hypertension has also been reported by the previous studies (29-31). Recently, Patel et al. (7) also reported positive association between leptin and DBP. The relationship between leptin and hypertension was also studied by Sabatier et al. (8), and their results illustrated that leptin-mediated actions may be diminished not only by reducing leptinproducing adipose tissue, but also by increasing physical activity in individuals with high levels of adiposity. Another recent study (9) has reported increased leptin levels among hypertensive elderly subjects.

Fall in $\mathrm{E}_{2}$ level followed by decreased leptin level in the normotensive as well as hypertensive Post-M women as compared to the Pre-M subjects suggests that $\mathrm{E}_{2}$ may be involved in controlling leptin level, and fall in $\mathrm{E}_{2}$ level at menopause may cause drop in the level of leptin in Post$\mathrm{M}$ women. A link has been suggested between $\mathrm{E}_{2}$ and leptin levels in women (32). A significant increase in the serum leptin concentrations on the 10th, 17th, and 24th day during the menstrual cycle suggested a possible role for estrogen in the stimulation of leptin secretion (33). However, there are contradictory findings regarding the relationship between $\mathrm{E}_{2}$ and leptin concentration. Di Carlo et al. (34) observed an increased serum leptin level in the untreated Post-M women as compared to the Pre-M subjects. The relationship between leptin and $E_{2}$ in obese subjects has not been established. So, the possible stimulatory action of $E_{2}$ on leptin needs to be confirmed by further studies.

The major finding of the present study is the correlation between leptin and BP in hypertensive Pre$\mathrm{M}$ and Post-M women. The present study is supported by the findings of Kennedy et al. (35) who demonstrated the relationship between elevated SBP and DBP and plasma leptin levels in hypertensive men, whereas Suter et al. (27) reported a significant relationship between SBP and plasma leptin levels in hypertensive women but not in hypertensive men. Correlation of leptin with BMI and FM has also been reported earlier (10, 36, 37).

Based on the significant correlation observed between $\mathrm{BP}$ and leptin level in the hypertensive subjects and not in normotensive subjects, it is suggested that leptin may be a regulator of BP in hypertensive subjects only. The association between leptin and BP seems to be independent of some potentially important variables such as BMI, FM, and menopausal status. These findings may further contribute to understanding the association between leptin levels and hypertension, a major factor that causes cardiovascular complications.

\section{Declaration of interest}

The authors declare that there is no conflict of interest that could be perceived as prejudicing the impartiality of the research reported.

\section{Funding}

This study was partly supported by research grant from University Grant Commission, India, to K K Khokhar.

\section{Acknowledgements}

All the subjects who contributed in the fulfillment of this work are duly acknowledged.

\section{References}

1 Flier JS. Leptin expression and action: new experimental paradigm. PNAS 199794 4242-4245. (doi:10.1073/pnas.94.9.4242)

2 Campfield LA, Smith FJ, Guisez Y, Devos R \& Burn P. Recombinant mouse OB protein: evidence for a peripheral signal linking adiposity and central neural network. Science $1995 \mathbf{2 6 9}$ 546-549. (doi:10.1126/science.7624778)

3 Ma D, Feitosa MF, Wilk JB, Laramie JM, Yu K, Leiendecker-Foster C, Myers RH, Province MA \& Borecki IB. Leptin is associated with blood pressure and hypertension in women from the National Heart, Lung, and Blood Institute Family Heart Study. Hypertension 2009 53 473-479. (doi:10.1161/HYPERTENSIONAHA.108.118133)

4 Schorr U, Blaschke K, Turan S, Distler A \& Sharma AM. Relationship between angiotensinogen, leptin and blood pressure levels in young normotensive men. Journal of Hypertension 1998 16 1475-1480. (doi:10.1097/00004872-199816100-00011)

5 Hirose H, Saito I, Tsujioka M, Mori M, Kawabe H \& Saruta T. The obese gene product, leptin: possible role in obesity-related hypertension in adolescents. Journal of Hypertension $1998 \mathbf{1 6}$ 2007-2012. (doi:10.1097/00004872-199816121-00023)

6 Barba G, Russo O, Siani A, Iacone R, Farinaro E, Gerardi MC, Russo P, Valle ED \& Strazzullo P. Plasma leptin and blood pressure in men: graded association independent of body mass and fat pattern. Obesity Research 200311 160-166. (doi:10.1038/oby. 2003.25)

7 Patel JV, Lim HS, Dubb K, Hughes EA \& Lip GYH. Circulating levels of adiponectins, leptin, and tumor necrosis factor $\alpha$ in hypertension. Annals of Medicine $2009 \mathbf{4 1}$ 291-300. (doi:10.1080/ 07853890802672839)

8 Sabatier MJ, McCully KK, Marinik EL, Schwark EH, Haddow S, Cortez-Cooper M, Bergeron MF, Sloan GJ \& Cannon JG. Leptin, blood pressure, and aerobic capacity in women. American Journal of Hypertension 200821 1245-1250. (doi:10.1038/ajh.2008.254)

9 Kramer CK, von Muhlen D \& Barrett-Connor E. Does leptin predicts incident hypertension in older adults? Clinical Endocrinology 2010 73 201-205. (doi:10.1111/j.1365-2265.2010.03781.x)

10 Rosenbaum M, Nicolson M, Hirsh J, Hemsfield SB, Gallagher D, Chu F \& Liebel RL. Effect of gender, body composition and menopause on plasma concentrations of leptin. Journal of Clinical Endocrinology and Metabolism $1996 \mathbf{8 1}$ 3424-3427. (doi:10. $1210 /$ jc.81.9.3424)

11 Bravo PE, Morse S, Borne DM, Aguilar EA \& Reisin E. Leptin and hypertension in obesity. Vascular Health and Risk Management 2006 2 163-169. (doi:10.2147/vhrm.2006.2.2.163) 
12 Stenvinkel P. Leptin and blood pressure - is there a link? Nephrology, Dialysis, Transplantation $2000 \quad 15$ 1115-1117. (doi:10.1093/ndt/15.8.1115)

13 WHO (World Health Organization Scientific Group). Research on the Menopause. WHO Technical Report Series, 1996 866. World Health Organization, Geneva.

14 Weiner JS \& Lourie JA. Practical Human Biology New York: Academic Press, Inc., 1981.

15 WHO (World Health Organization) and IOTF (International Obesity Task Force): The Asia specific perspective redefining obesity and its treatment. International Diabetes Institute. Health Communication Australia Pvt. Ltd, Geneva, 2000.

16 Rose GA \& Blackburn H. Cardiovascular survey methods. Monograph Series. World Health Organization 196856 90-95.

17 JNC VII. The seventh report of the Joint National Committee on Prevention, Detection, Evaluation and Treatment of High Blood Pressure. Journal of the American Medical Association 2003289 2560-2572. (doi:10.1001/jama.289.19.2560)

18 Durnin JVGA \& Womerslay J. Body fat assessment from total body density and its estimation from skinfold thickness: measurement on 481 men and women aged from 16 to 72 year. British Journal of Nutrition 197432 77-97. (doi:10.1079/BJN19740060)

19 Ushiroyama T, Ikeda A, Higashio S, Sakuma K \& Ueki M. Elevated plasma leptin levels associated with high blood pressure and TG rich lipoproteins but not associated with plasma gonadotrophins, estradiol and cortisol levels in peri- and postmenopausal lean women with undefined symptoms. Journal of Medicine 200435 $63-73$.

20 Haque Z, Lakho GR, Nafees M, Shahid KU \& Mazahir I. Serum leptin levels correlation with high blood pressure in adult females. Journal of College of Physicians and Surgeons Pakistan 200616 450-454.

21 Galleti F, D’Elia L, Barba G, Siani A, Cappuccio FP, Farinaro E, Iacone R, De Palma D, Ippolito R \& Strazzullo P. High circulating leptin levels are associated with greater risk of hypertension in men independent of body mass and insulin resistance: results of an eight year follow up study. Journal of Clinical Endocrinology and Metabolism 2008 93 3922-3926. (doi:10.1210/jc.2008-1280)

22 Beltowski J. Role of leptin in blood pressure regulation and arterial hypertension. Journal of Hypertension 2006 24 789-801. (doi:10. 1097/01.hjh.0000222743.06584.66)

23 Karlson C, Lindell K, Ottoson M, Sjostrom L, Carlsson B \& Carlsson LM. Human adipose tissue expresses angiotensinogen and enzyme required for its conversion to angiotensin II. Journal of Clinical Endocrinology and Metabolism $1998 \mathbf{8 3} 3925-3929$. (doi:10.1210/jc.83.11.3925)

24 Snikter S, Pratley RE, Nicolson M, Tataranni PA \& Ravussin E. Relationship between muscle sympathetic nerve activity and plasma leptin concentrations. Obesity Research 19975 338-340.

25 Hankinson AL. Epidemiologic and pathophysiologic links between obesity and hypertension. Current Cardiovascular Risk Reports 2009 3 264-271. (doi:10.1007/s12170-009-0041-8)

26 Narkiewicz K, Somers VK, Mos L, Kato M, Accurso V \& Palatini P. An independent relationship between plasma leptin and heart rate in untreated patients with essential hypertension. Journal of Hypertension 199917 245-249.
27 Suter PM, Locher R, Hasler E \& Vetter W. Is there a role for the ob gene product leptin in essential hypertension? American Journal of Hypertension 199811 1305-1311. (doi:10.1016/ S0895-7061(98)00162-9)

28 Canatan H, Bakan I, Akbulut M, Baydas G, Halifeoglu L \& Gursu MF. Comparative analysis of plasma leptin levels in both genders of patients with essential hypertension and healthy subjects. Endocrine Research 2004a 30 95-105. (doi:10.1081/ ERC-120029889)

29 Haynes WG. Role of leptin in obesity related hypertension. Experimental Physiology 200590 683-688. (doi:10.1113/ expphysiol.2005.031237)

30 Agata J, Masuda A, Takada M, Higashiura K, Murakami H, Miyazaki Y \& Shimamoto K. High plasma immunoreactive leptin levels in essential hypertension. American Journal of Hypertension 199710 1171-1174. (doi:10.1016/S0895-7061(97)00310-5)

31 Uckaya G, Ozata M, Sonmez A, Kinalp C, Eyileten T, Bingol N, Koc B, Kocabalkan F \& Ozdemir IC. Plasma leptin levels strongly correlaye with plasma rennin activity in patients with essential hypertension. Hormone and Metabolic Research 199931 435-438. (doi:10.1055/s-2007-978769)

32 Shimizu H, Shimomura Y, Nakanishi Y, Futawatari T, Ontani K, Sato $\mathrm{N} \&$ Mori M. Estrogen increases in vivo leptin production in rats and human subjects. Journal of Endocrinology $1997 \mathbf{1 5 4}$ 285-292. (doi:10.1677/joe.0.1540285)

33 Mannucci E, Ognibene A, Becorpi A, Cremasco F, Pellegrini S, Ottanelli S, Rizzello SM, Massi G, Messeri G \& Rotella CM. Relationship between leptin and oestrogen in healthy women. European Journal of Endocrinology 1998139 198-201. (doi:10. 1530/eje.0.1390198)

34 Di Carlo C, Tommaselli GA, Gargano V, Sammartino A, Bifulco G, Tauchmanova L, Calao A \& Nappi C. Effects of estrogen-progestin therapy on serum levels of RANKL, osteoprotegerin, osteocalcin, leptin, and ghrelin in postmenopausal women. Menopause 2007 14 7-9. (doi:10.1097/GME.0b013e31802d0481)

35 Kennedy A, Gettys TW, Watson P, Wallace P, Ganaway E, Pan Q \& Garvey WT. The metabolic significance of leptin in humans: gender-based differences in relationship to adiposity, insulin sensitivity, and energy metabolism. Journal of Clinical Endocrinology and Metabolism 199782 1293-1300. (doi:10.1210/jc.82.4. 1293)

36 Considine RV, Sinha MK, Heiman ML, Kriauciunas A, Stephens TW, Nyce MR, Ohannesian JP, Marco CC, McKee LJ, Bauer TL \& Caro JF. Serum immunoreactive-leptin concentrations in normal-weight and obese humans. New England Journal of Medicine 1996334 292-295. (doi:10.1056/NEJM1996020 13340503)

37 Hadji P, Hars O, Bock K, Sturm G, Bauer T, Emons G \& Schulz KD. The influence of menopause and body mass index on serum leptin concentrations. European Journal of Endocrinology 2000143 55-60. (doi:10.1530/eje.0.1430055)

Received 19 August 2010

Accepted 14 September 2010 